\title{
PEMANFAATAN LIMBAH CANGKANG KERANG HIJAU SEBAGAI KERUPUK KEMPLANG DALAM UPAYA PENINGKATAN KESEJAHTERAAN MASYARAKAT DESA DOMAS KECAMATAN PONTANG PROVINSI BANTEN
}

\author{
Fadilatun Nisa ${ }^{1}$ \\ Kurniasih Dwi Astuti ${ }^{*}$ \\ Anis Maryanih ${ }^{3}$ \\ Adinda Syafa Taqila ${ }^{4}$ \\ Nuraeni Noviyanti ${ }^{5}$ \\ Cinta Cantika Putri Affanti6
}

1,2,3,4,5,6Universitas Sultan Ageng Tirtayasa, Serang, Indonesia

fadilatunnisa8@gmail.com ${ }^{1)}$ nien rz@untirta.ac,id $\left.{ }^{*}\right)$ anis.maryanh29@gmail.com ${ }^{3)}$ adindasyafataqila@gmail.com ${ }^{4}$ nuraeninoviyanti2878@gmail.com ${ }^{5}$ ) cintacantikaaffanti@gmail.com ${ }^{6}$

Kata Kunci: [Desa domas, , Kerang Hijau, kerupuk kemplang]

\begin{abstract}
Abstrak: Desa domas merupakan desa pesisir yang memiliki potensi lokal yaitu kerang hijau. Selain itu, desa domas memiliki permasalahan di sektor lingkungan dan ekonomi. Kegiatan pengabdian kepada masyarakat ini bertujuan untuk menciptakan produk olahan kerupuk kemplang dari cangkang kerang hijau melalui pemberdayaan masyarakat di desa domas, kabupaten serang, provinsi banten. Target khusus yang diharapkan dari kegiatan ini adalah memberikan pemahaman terkait pengolahan limbah cangkang kerang hijau menjadi produk baru yang memiliki nilai ekonomis yang tinggi. Kegiatan ini dilakukan selama 2 bulan secara daring dan luring dimana dalam kegiatan ini terdiri atas kegiatan pelatihan produksi kerupuk kemplang, pengemasan, serta pemasaran produk baik online maupun offline. Hasil kegiatan ini berupa produk kerupuk kemplang dari cangkang kerang hijau khas desa domas serta dapat mengurangi permasalahan baik lingkungan dan ekonomi.
\end{abstract}

Published by:

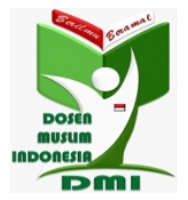

Copyright (C) 2021 The Author(s)

This article is licensed under CC BY 4.0 License (cc) BY 


\section{Pendahuluan}

Desa Domas merupakan salah satu desa yang terletak di Kabupaten Serang bagian utara Provinsi Banten yang termasuk dalam daerah pesisir dengan jumlah penduduk di tahun 20184.478 orang terdiri atas 2.430 laki-laki dan 2.048 perempuan (BPS, 2018). Sebagian besar penduduk desa domas hanya lulusan sekolah dasar (SD) dan hanya sekitar 30\% yang melanjutkan ke jenjang SMP (Wigati et al., 2018). Masyarakat Desa Domas bermata pencaharian sebagai nelayan kecil bagi kaum laki-laki dimana hasil tangkapan ikan dijual kepada tengkulak yang nilai jualnya lebih rendah dari pada nilai jual di pasar. Sedangkan para wanita rata-rata tidak bekerja, hanya sebagian yang bekerja sebagai buruh pemisah cangkang kerang hijau dengan upah yang cukup rendah. Pekerjaan yang mereka tekuni bukanlah pekerjaan dengan gaji yang tinggi bahkan pendapatan tersebut jika akumulasikan perbulan masih dibawah Upah Minimum Kabupaten Serang. Oleh karena itu, kesejahteraan Desa Domas berada pada tingkat ekonomi rendah.

Berdasarkan hasil observasi, Desa Domas merupakan desa yang memiliki potensi alam lokal yang melimpah salah satunya kerang hijau dimana dalam sehari pengusaha kerang hijau dapat menghasilkan \pm 1 ton kerang hijau. Potensi lokal tersebut belum dimanfaatkan secara optimal oleh masyarakat setempat karena kurangnya skill serta pengetahuan dalam pengolahan. Pengusaha kerang hijau hanya menjual bahan baku dalam bentuk mentah tanpa proses terlebih dahulu. Besarnya kerang hijau yang didapatkan menghasilkan limbah cangkang kerang yang cukup tinggi sehingga diperlukan upaya serius untuk menanganinya agar dapat bermanfaat dan mengurangi dampak negatif terhadap lingkungan.

Salah satu upaya yang dilakukan untuk mengatasi permasalahan tersebut adalah dengan diversifikasi pangan yaitu pengolahan limbah cangkang kerang hijau menjadi produk baru yang bernilai jual tinggi. Selama ini tanpa kita sadari cangkang kerang hijau banyak mengandung mineral dan kalsium yang tinggi sebesar 38\% (Ainurrohma, 2018). Meskipun demikian masih banyak yang belum mengetahui dan masih sedikit yang memanfaatkannya. Padahal jika ditelisik lebih jauh, cangkang kerang hijau dapat dijadikan sebagai sumber tepung baru yang dapat digunakan untuk keperluan membuat olahan pangan (Permana, 2006). Oleh karena itu, diharapkan produk kerupuk kemplang menjadi produk inovatif yang berbahan baku limbah cangkang kerang hijau serta dapat memberikan solusi atas permasalahan ekonomi serta lingkungan di desa domas. Sehubungan dengan hal tersebut, kegiatan ini perlu dilaksanakan. Kegiatan ini merupakan bentuk pengabdian kepada masyarakat sebagai implementasi dari Tri Dharma Perguruan Tinggi. Kegiatan ini bertujuan untuk memberikan pengetahuan tentang cara mengolah limbah cangkang kerang hijau menjadi sebuah produk yang bernilai jual tinggi.

\section{Metode Pelaksanaan}

Kegiatan ini dilaksanakan pada juni-agustus 2021 bertempat di Desa Domas, Kabupaten Serang, Provinsi Banten. Kegiatan diawali dengan identifikasi masalah melalui kegiatan observasi di lokasi. Pelaksanaan program dimulai dengan sosialisasi kegiatan, kemudian dilakukan pembagian kelompok antar tim pelaksana dan ibu ibu pkk yang terdiri dari tim produksi, tim pengemasan dan tim pemasaran. Sasaran pelaksanaan kegiatan yaitu ibu-ibu pkk terutama masyarakat desa domas. Jumlah peserta yang mengikuti program ini kurang lebih 30 orang yang terdiri dari ibu-ibu pkk, masyarakat desa setempat, dan tim PKM-PM Universitas Sultan Ageng Tirtayasa dengan tetap 
menerapkan protokol kesehatan. Metode kegiatan yang digunakan pada kegiatan pengabdian kepada masyarakat ini adalah dengan penyuluhan dan praktik langsung.

\section{Hasil dan Pembahasan}

Berdasarkan hasil observasi yang dilakukan, terdapat banyak limbah cangkang kerang hijau serta daging kerang hijau yang belum dimanfaatkan secara optimal oleh masyarakat setempat. Berdasarkan hal tersebut civitas academica tertarik untuk melaksanakan kegiatan PKM bidang pengabdian kepada masyarakat berupa pelatihan serta pendampingan mengenai pembuatan limbah cangkang kerang hijau menjadi kerupuk kemplang bersama tim pelaksana dan ibu-ibu pkk serta masyarakat setempat yang dilaksanakan secara hybrid dari bulan juni-agustus 2021. Adapun tahapan pelaksanaan pengabdian kepada masyarakat yaitu tahap persiapan, pelaksanaan dan evaluasi.

Pada Tahap persiapan, tim pelaksana PKM Pengabdian kepada Masyarakat melakukan kesepakatan kerjasama bersama mitra yaitu ibu-ibu pkk dan masyarakat desa domas yang dilaksanakan secara offline (lihat gambar 1)

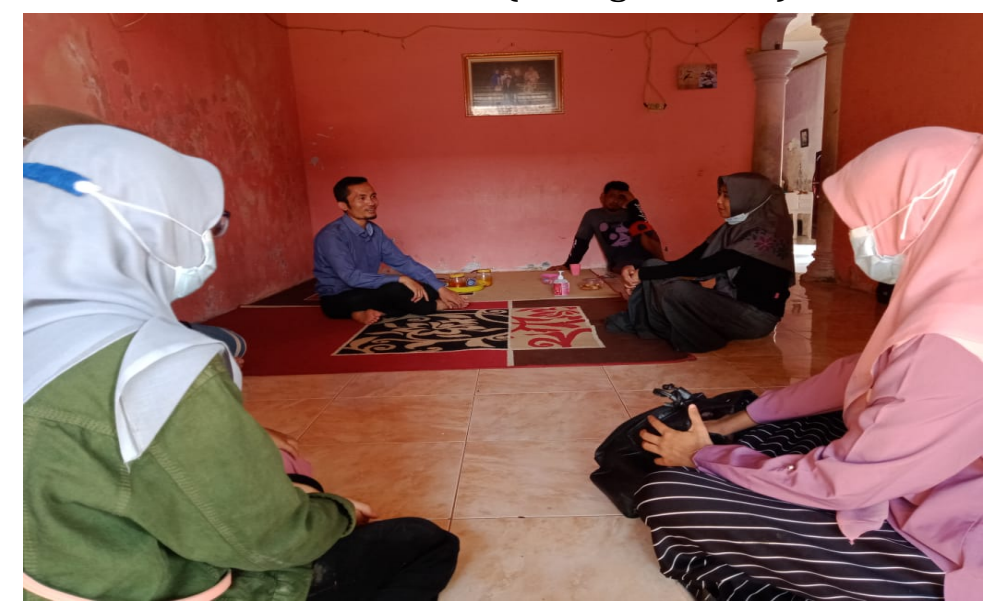

Gambar 1. Menjalin Kerjasama bersama ibu-ibu pkk

Pada tahap pelaksanaan kegiatan dilakukan dalam beberapa tahap yaitu tahap sosialisasi, taahap pembentukan organisasi masyarakat, tahap pelatihan pembuatan produk, tahap pelatihan pembuatan pemasaran baik online maupun offline dan tahap penjualan.

\section{Tahap Sosialisasi Program Pembuatan Kerupuk Kemplang Cangkang Kerang Hijau}

Kegiatan sosialisasi diawali dengan menjelaskan program kreativitas mahasiswa bidang pengabdian kepada masyarakat serta menjelaskan terkait pengolahan limbah cangkang kerang hijau ke ibu-ibu pkk dan masyarakat setempat. Hasil yang di dapatkan dari kegiatan tersebut yaitu pembentukan tim pelaksanaan program yang terdiri dari ibu-ibu pkk dan masyarakat desa domas membagi menjadi 3 tim yaitu tim produksi, 
pengemasan dan pemasaran. Pada pelaksanaan setiap kelompok diberikan pendampingan oleh tim pelaksana PKM-PM Universitas Sultan Ageng Tirtayasa.
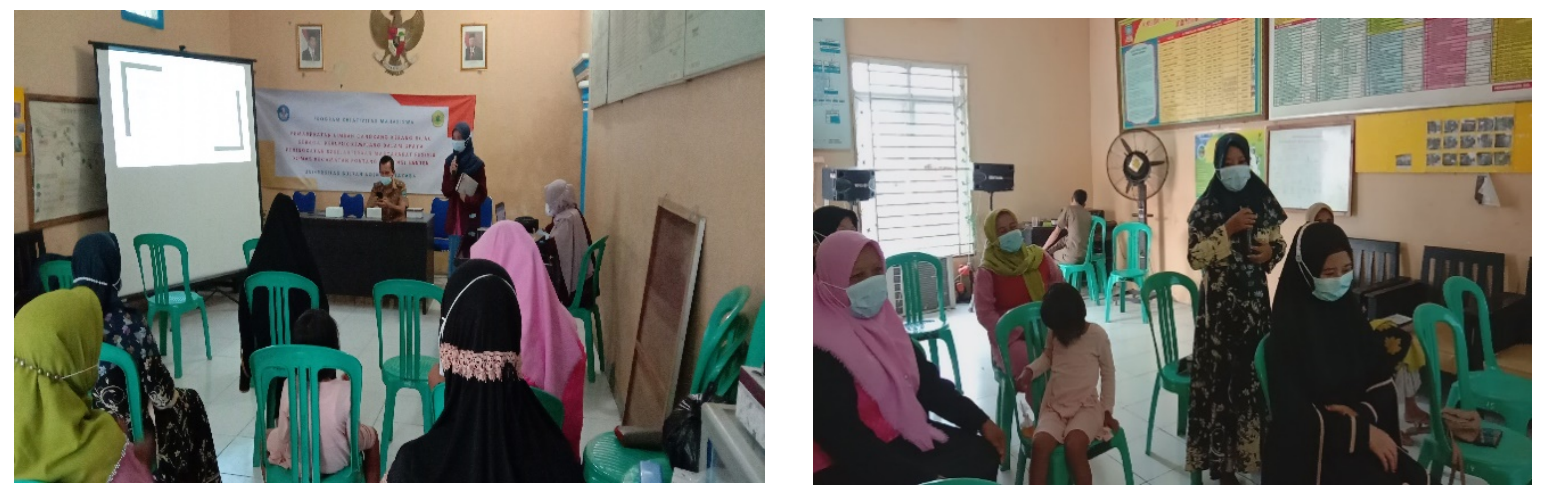

Gambar 2 Sosialisasi dan pembentukan kelompok

\section{Pembuatan Produk kerupuk kemplang}

Kemplang merupakan salah satu jenis kerupuk yang biasanya dibuat dari tepung dengan bahan campuran ikan. Kerupuk kemplang domas merupakan kerupuk yang bahan baku utamanya dari daging dan cangkang kerang hijau. Menurut permana (2006) tepung cangkang kerang hijau mengandung 0,85\% air, 4,14 \% protein, 3,55\% lemak, 3,55\% karbohidrat, 14,33\% abu, 33,56 \%kalsium, dan 0,12\% fosfor. Bahan baku utama dari kerupuk kemplang yaitu tepung cangkang keang hijau, tepung tapioka, daging kerang hijau dengan perbandingan 1:3:4. Penambahan daging kerang hijau digunakan agar kerupuk kemplang memiliki rasa khas dari kerang hijau. Komposisi yang digunakan dalam pembuatan kerupuk kemplang adalah tepung cangkang kerang hijau, daging cangkang kerang hijau, tepung tapioka, tepung sagu, bawang putih, bawang merah, garam, penyedap rasa dan air.

Langkah awal pembuatan kerupuk kemplang kerang hijau yaitu pembuatan tepung cangkang kerang hijau, dimana cangkang kerang hijau yang digunakan berukuran kecil. Cangkang Kerang hijau dibersihkan untuk direbus lalu di jemur sampai kering kemudian di giling dengan mesin penggilingan khusus kerang. Setelah tepung kerang hijau dihasilkan, langkah selanjutnya yaitu pembuatan kerupuk kemplang. Dimana dalam pembuatan kemplang yaitu tepung cangkang kerang hijau, tepung tapioka, daging cangkang kerang hijau dicampur dengan bumbu. Setelah itu, adonan dicetak untuk kemudian dikukus sekitar 30 menit. Setelah proses pengukusan, kemplang setengah jadi di diamkan sampai dingin dan bertekstukr keras untuk diiris tipis-tipis. Kerupuk yang sudah diiris lalu di jemur dibawah sinar matahari langsung selama 2-3 hari. Setelah kerupuk benar-benar kering dilakukan penggorengan kemudian dikemas. Kerupuk kemplang dikemas menggunakan plastik ukuran $15 \times 25 \times 0.5 \mathrm{~cm}$. Pemasaran produk kerupuk kemplang di laksanakan via online dan juga offline memalui toko oleh-oleh yang ada di Provinsi Banten. 

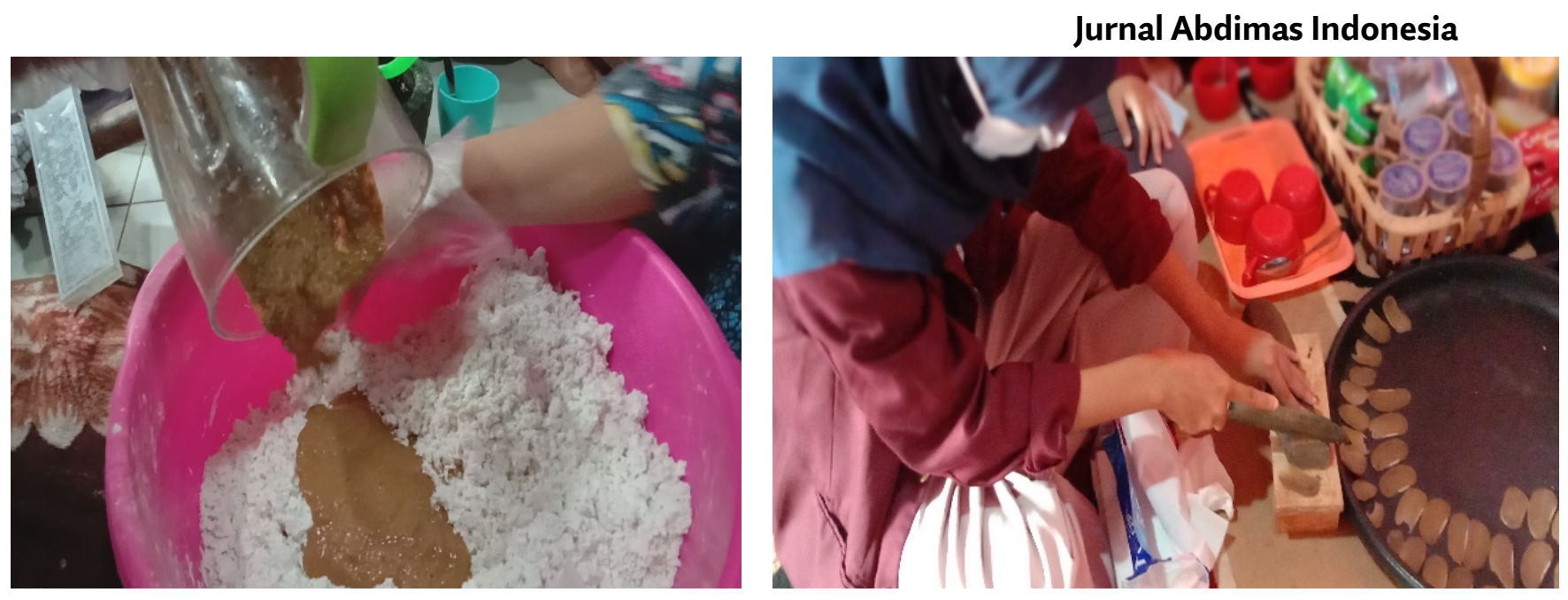

Gambar 3 pembentukan kerupuk kemplang
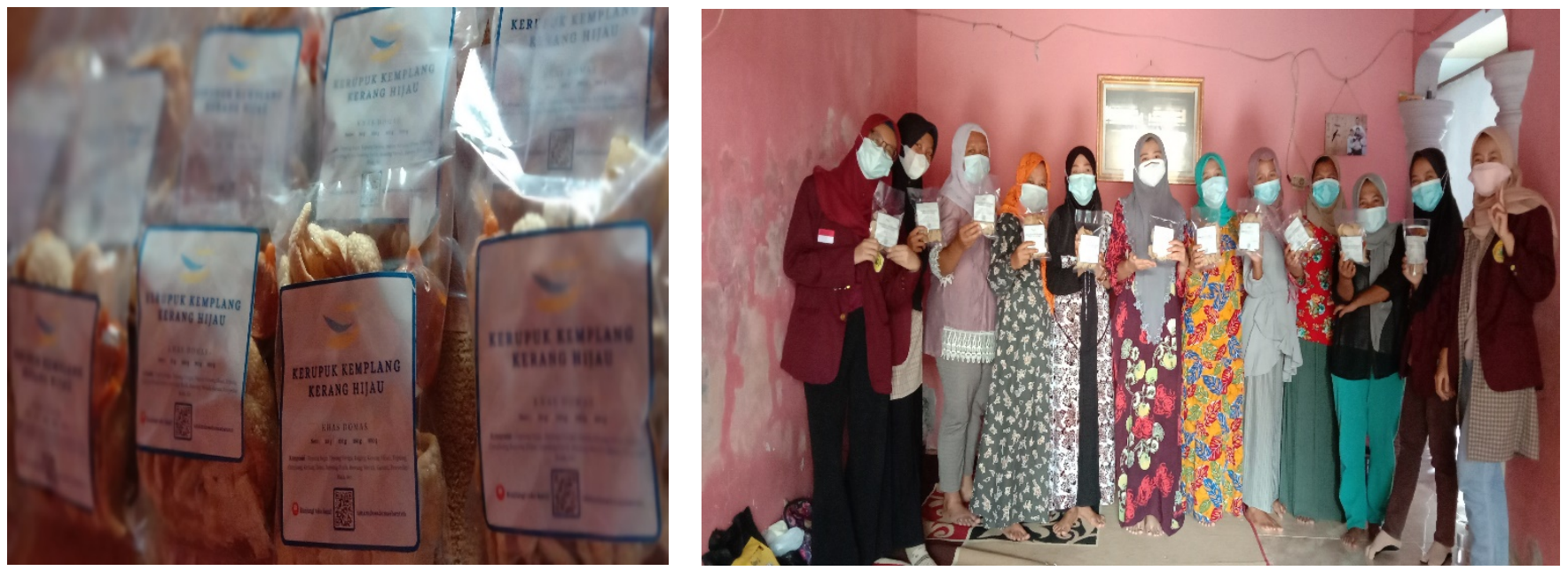

Gambar 4 produk matang kerupuk kemplang

Kegiatan dilanjutkan dengan pendampingan dan evaluasi bagi kelompok ibu-ibu pkk untuk melihat sejauh mana pengetahuan serta pendapatan yang didapatkan masyarakat setempat. Kegiatan pendampingan dilakukan setiap pekan secara online melalui group whatsapp.

\section{Kesimpulan}

Hasil kegiatan pengabdian yang telah dilakukan terciptanya produk kerupuk kemplang cangkang kerang hijau, sehingga dapat membantu meningkatkan pendapatan serta limbah cangkang kerang hijau di Desa Domas Provinsi Banten.

\section{Ucapan Terimakasih}

Ucapan terima kasih kepada Kementrian Riset, Teknologi dan Pendidikan Tinggi (kemensristekdikti) atas hibah yang diberikan melalui program kreativitas mahasiswa (PKM) 2021 sehingga program ini bisa terlaksana.

\section{Referensi}

Ainurrohma, Dwinda. 2017. Pengaruh Penambahan Tepung Cangkang Kerang Hijau (Pernaviridis) Terhadap Karakteristik Cookies Kaya Kalsium. Skripsi. Fakultas Perikanan Dan Ilmu Kelautan Universitas Brawijaya, Malang. 
Vol. 1. No. 2, Agustus 2021

Permana H. 2006. Optimalisasi Pemanfaatan Cangkang Kerang Hijau (Pernaviridis) dalam Pembuatan Kerupuk. Skripsi. Fakultas Perikanan dan Ilmu Kelautan Institut Pertanian Bogor, Bogor.

Wigati R, Kulsum dan Rindu B.T. 2018. Pemberdayaan Kawasan Pesisir Utara Banten Melalui Kelompok Usaha Bersama Berbasis Kearifan Lokal. URL: www.jurnal.untirta.ac.id . Diakses tanggal 5 November 2020. 